Universidade de São Paulo

Paulo Henrique Garcia Hermosilla

\title{
A EXISTÊNCIA DO CASAMENTO ENTRE PESSOAS DO MESMO SEXO
}

Dissertação de mestrado

Orientador: Dr. Carlos Alberto Dabus Maluf

Faculdade de Direito

São Paulo

2014 


\title{
UNIVERSIDADE DE SÃO PAULO
}

MESTRADO EM DIREITO CIVIL

Paulo Henrique Garcia Hermosilla

\section{A EXISTÊNCIA DO CASAMENTO ENTRE PESSOAS DO MESMO SEXO}

\begin{abstract}
Dissertação de mestrado apresentada ao Programa de Mestrado da Faculdade de Direito da Universidade de São Paulo - USP como parte dos requisitos para obtenção do título de Mestre em Direito Civil, sob orientação do prof. Dr. Carlos Alberto Dabus Maluf.
\end{abstract}

Faculdade de Direito

São Paulo

2014 


\section{ATESTADO DE AUTORIA E CESSÃO DE DIREITOS}

NOME DO AUTOR: Paulo Henrique Garcia Hermosilla

TÍTULO DO TRABALHO: A existência do casamento entre pessoas do mesmo sexo. TIPO DO TRABALHO/ANO: Dissertação/2013

Conforme Lei $\mathrm{n}^{\mathrm{o}}$ 9.610, de 19 de fevereiro de 1998, o autor declara ser inteiramente responsável pelo conteúdo desta dissertação e concede à Universidade de São Paulo permissão para reproduzi-la, bem como emprestá-la, ou, ainda, vender cópias, somente para propósitos acadêmicos e científicos. O autor reserva outros direitos de publicação, e nenhuma parte desta dissertação pode ser reproduzida sem a sua autorização.

Paulo Henrique Garcia Hermosilla

Rua Emílio Ribas, 140, apt 74 - Cambuí

13025-140 - Campinas - SP

hermosilla@usp.com 
Dissertação aprovada em sua versão final pela banca examinadora:

Prof. Dr. Carlos Alberto Dabus Maluf

Orientador - Universidade de São Paulo

Prof. Dr.

Prof. Dr.

São Paulo/SP, ___ _ _ L 
Aos que me acompanharam nessa jornada, e me encorajaram com seu amor incondicional, em especial Alessandra, Giulia e Matteo. 


\section{AGRADECIMENTOS}

Agradeço ao meu orientador, Prof. Dr. Carlos Alberto Dabus Maluf, por todos os anos que trabalhamos juntos, pelo carinho que recebi e por viabilizar este trabalho.

Ao Dr. Joaquim Portes de Cerqueira Cesar, pelo apoio e estímulo inestimáveis.

A todos aqueles que, direta ou indiretamente, contribuíram para a realização deste trabalho. 


\section{RESUMO}

Em matéria de casamento, a doutrina majoritária sustenta que as causas de nulidade devem ser textuais ou expressas, não se admitindo nulidades virtuais. Nesse ambiente, surgiu a teoria da inexistência, criada pela doutrina como forma de impugnação do casamento realizado na ausência de seus elementos fundamentais: consentimento, celebração, e dualidade de sexo. Tal teoria, já conhecida pelos canonistas, foi desenvolvida e divulgada após a Revolução Francesa, a partir dos estudos do jurista tedesco Zachariae von Linghental, a partir dos comentários de Napoleão Bonaparte junto ao Conselho de Estado francês, quando da elaboração do Código Civil francês de 1804. O objetivo deste trabalho é analisar, após dois séculos dos estudos de Zachariae, o impacto sofrido pela teoria da inexistência a partir da aprovação, por diversos países, do casamento entre pessoas do mesmo sexo. A partir surgiu o seguinte problema de pesquisa: existe o casamento entre pessoas do mesmo sexo? A pesquisa percorreu as seguintes etapas: pesquisa doutrinária, com ênfase para a doutrina francesa do século XIX, e pesquisa jurisprudencial nacional. O principal resultado alcançado, após as leituras e pesquisas efetuadas, foi a conclusão de que, hoje, no Brasil, a existência jurídica do casamento entre pessoas do mesmo sexo é uma realidade.

Palavras-chave: Zachariae. Homoafetivo. Casamento. Nulidade. Inexistência. 


\begin{abstract}
On marriage, the majority doctrine holds that the grounds of invalidity should be textual or expressed, not admitting virtual nonentities. Consent, celebration, and duality of sex: In this environment, the lack of theory, created by the doctrine as a way of challenging the marriage in the absence of its key elements emerged. Such a theory, now known by the canonists, was developed and released after the French Revolution, from the studies of boredom jurist Zachariae von Linghental, from the comments of Napoleon Bonaparte by the French Council of State, when preparing the French Civil Code 1804. The objective of this work is to analyze, after two centuries of dissemination of studies Zachariae, the impact suffered by the theory of absence from the adoption by many countries, marriage between persons of the same sex. From the following research problem emerged: is there a marriage between persons of the same sex? The research has taken the following steps: doctrinal research, with emphasis on the French doctrine of the nineteenth century, and national case search. The main result achieved after the readings and performed research, was the finding that, today, in Brazil, the legal existence of marriage between persons of the same sex is a reality.
\end{abstract}

Keywords: Zachariae. Same-sex. Marriage. Nonentities. Non-existence 


\section{SUMÁRIO}

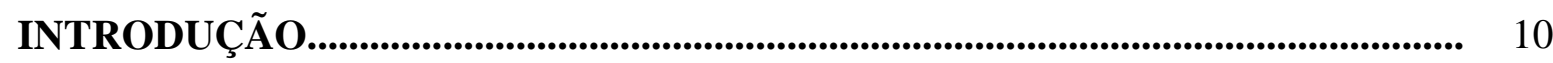

1 HISTÓRICO E CONTEXTUALIZAÇÃO................................................................ 15

2 A DUALIDADE DE SEXO COMO ELEMENTO DE EXISTÊNCIA DO

CASAMENTO À LUZ DA ESCOLA DA EXEGESE .................................................... 24

3 A EXPERIÊNCIA DO DIREITO ESTRANGEIRO QUANTO AO

CASAMENTO DE PESSOAS DO MESMO SEXO ...................................................... 39

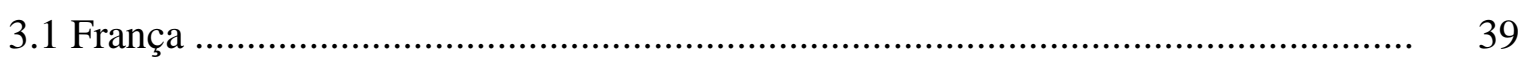

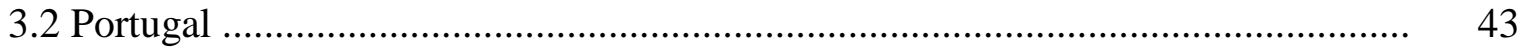

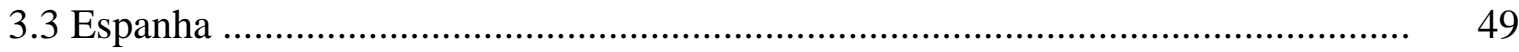

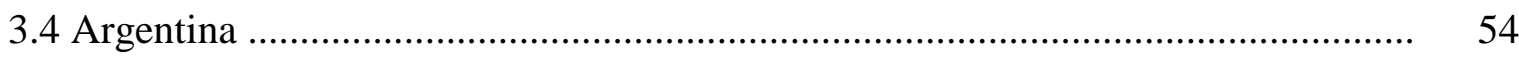

3.5 Outros países ………………………………………………………….... 57

4 O CASAMENTO DE PESSOAS DO MESMO SEXO NO DIREITO

BRASILEIRO ........................................................................................................................... 61

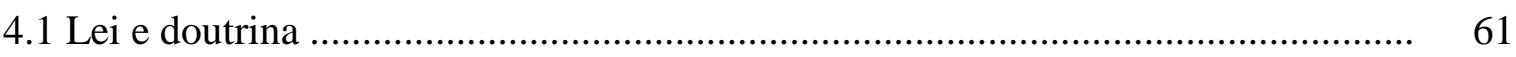

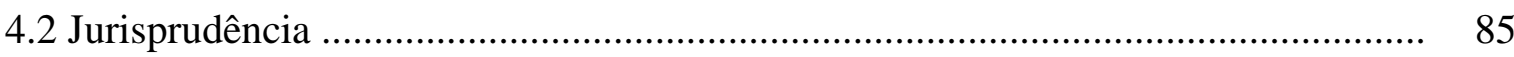

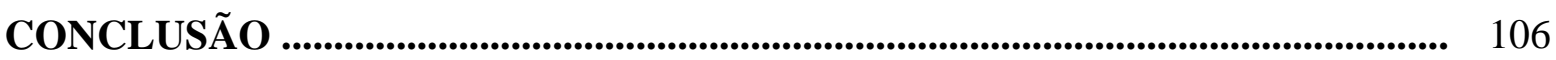

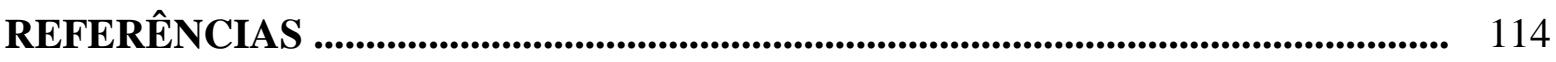

